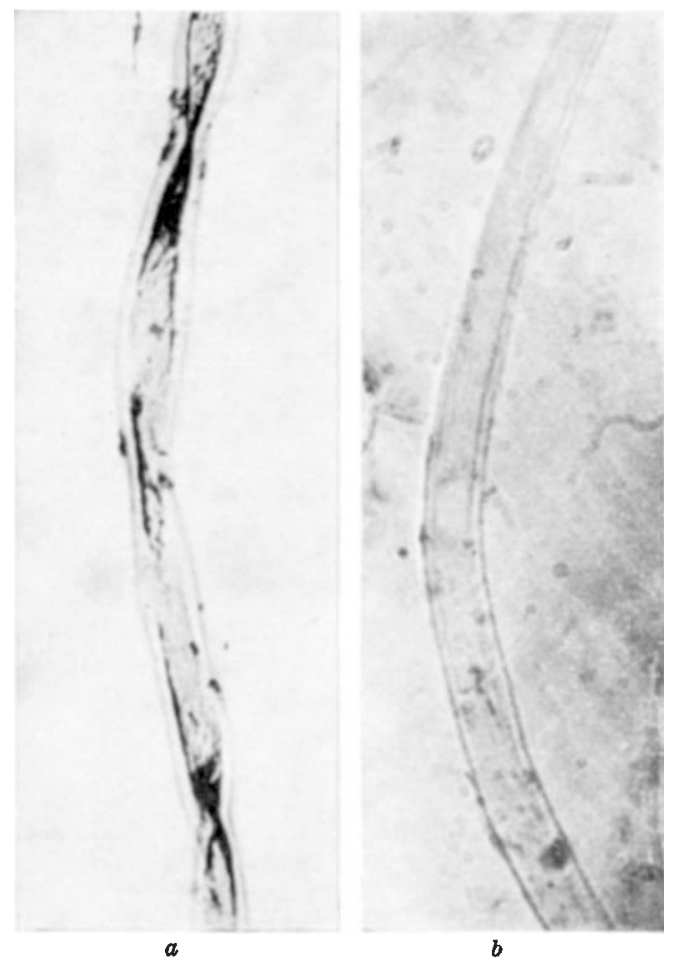

Fig. 2. Hairs of cotton seed from Afyeh: (a) terminal unconvoluted end; (b) central convoluted section $(\times 450)$.

cottons with which it was compared-G. herbaceum var. africanum and $G$. arboreum var. soudanense.

There was no archaeological evidence that the inhabitants of Afyeh made textiles. The nature of the organic material and the situation in which it was found suggest that the seeds were part of a small heap of feed and dung from a shed in which sheep or goats were kept. Thus we have the first evidence that cotton seeds were collected and fed to livestock before cotton lint was used for making textiles. This does not support Hutchinson's suggestion that no true cotton is indigenous to the Nile region and that $G$. arboreum var. soudanense was introduced from India for use as a textile raw material. A true cotton indistinguishable from it on archaeological evidence must have been indigenous to Nubia.

We thank Dr J. H. Saunders of the Cotton Research Breeding Station, Khartoum, for cotton seeds. We also thank Sir Joseph Hutchinson for help and advice.

K. A. Chowdhury

G. M. ВUTH

Department of Botany,

Aligarh Muslim University,

India.

Received April 7, 1970.

1 Ghosh, A., Indian Archaeology, 1961-62, 68 (1964).

${ }^{2}$ Hutchinson, J. B., The Application of Genetics to Cotton Improvement (Cambridge University Press, 1959).

${ }^{3}$ Hutchinson, J. B., Emp. Cotton Growers Rev. , 26, 1 (1949).

\section{Nitrogen in the Rainfall at Samaru, Nigeria}

IN 1960 , E. Jones ${ }^{1}$ reported an unusually high nitrogen level (5.355 p.p.m., representing $50 \cdot 8$ pounds/acre/annum, $56.9 \mathrm{~kg} /$ hectare $^{-1}$ per annum) and a high ratio of $\mathrm{NH}_{4}-\mathrm{N}$ to $\mathrm{NO}_{3}-\mathrm{N}$ (approximately $40: 1$ ) in Samaru (latitude $11 \cdot 11^{\circ} \mathrm{N}$, longitude $\left.7 \cdot 38^{\circ} \mathrm{E}\right)$ rainwater. Because an annual addition of nitrogen in such quantities to soils generally deficient in available nitrogen would be of great agricultural significance, we decided to check these figures. During 1969 rainwater was collected in open containers and analysed for $\mathrm{NH}_{4}-\mathrm{N}$ and $\mathrm{NO}_{3}-\mathrm{N}$ by steam distillation methods, as soon as possible after each shower. Table 1 gives the results on a monthly basis. For the whole year, the total addition of mineral nitrogen was found to be just over $4.5 \mathrm{~kg} /$ hectare $^{-1}$ (4 pounds/acre). This figure is supported by additional data from an independent study for the 4 months from June to September. (i) At Samaru at this time the mean air concen. tration of $\mathrm{NH}_{3}-\mathrm{N}$ was $2 \cdot 2 \mu \mathrm{g} \mathrm{m} \mathrm{m}^{-3}$ (mean of 17 determinations; range $1 \cdot 1-4 \cdot 2 \mu \mathrm{g} \mathrm{m}^{-3}$ ) and the mean rainwater $\mathrm{NH}_{4}-\mathrm{N}$ concentration was 0.18 p.p.m. The washout factor (personal communication from A. C. Chamberlain), $w=(\mathrm{mg} \mathbf{N}+/ \mathrm{l}$. of rainwater $) /(\mathrm{mg} \mathbf{N}+/ \mathrm{kg}$ of air $)$, of 80 calculated from these figures accords well with other values calculated from the literature ${ }^{2,3}$. (ii) Analyses of rainwater collected monthly at other stations in northern Nigeria revealed very similar total mineral nitrogen additions to that found for Samaru (Table 2).

\begin{tabular}{|c|c|c|c|c|c|c|}
\hline Month & $\begin{array}{c}\text { No. } \\
\text { of } \\
\text { showers }\end{array}$ & $\underset{(\mathrm{mm})}{\text { Rainfall }}$ & $\begin{array}{c}\text { Mean } \\
\text { shower } \\
\text { size } \\
\text { (mm) }\end{array}$ & $\begin{array}{c}\text { Mean } \\
\text { mineral-N } \\
\text { in rain } \\
\text { (p.p.m.) }\end{array}$ & $\begin{array}{c}\text { Mean } \\
\text { ratio } \\
\mathrm{NH}_{4}-\mathrm{N}: \\
\mathrm{NO}_{3}-\mathrm{N}\end{array}$ & $\begin{array}{c}\text { Annual } \\
\text { fleld } \\
\text { addition } \\
\text { (kg/ } \\
\text { hectare } \\
\text { (kg) }\end{array}$ \\
\hline $\begin{array}{l}\text { February } \\
\text { March }\end{array}$ & 1 & 0.3 & 0.3 & $3 \cdot 11$ & 0.86 & 0.008 \\
\hline April & 4 & $\overline{43} \cdot 2$ & $10 \cdot 8$ & $0 \cdot 81$ & 1.57 & $0 . \overline{349}$ \\
\hline May & 11 & $116 \cdot 8$ & $10 \cdot 6$ & 0.59 & $1 \cdot 30$ & 0.693 \\
\hline June & 18 & 184.7 & $10 \cdot 3$ & 0.39 & 1.02 & $0 \cdot 723$ \\
\hline July & 18 & $445 \cdot 5$ & 24.7 & 0.33 & 1.25 & 1.483 \\
\hline August & 27 & $233 \cdot 7$ & $8-7$ & $0 \cdot 28$ & 1.41 & 0.650 \\
\hline September & 15 & 89.9 & $6 \cdot 0$ & 0.30 & 0.98 & 0.272 \\
\hline October & 13 & 104.4 & 8.0 & 0.37 & $\begin{array}{l}1.46 \\
1.46\end{array}$ & $0 \cdot 387$ \\
\hline Year & 107 & $1, \overline{218 \cdot 5} *$ & $11 \cdot 4$ & 0.37 & $1 \cdot 26$ & $\overline{4.565}$ \\
\hline
\end{tabular}

(Extreme ranges recorded; p.p.m. mineral-N, $0 \cdot 11-3 \cdot 11 ; \mathrm{NH}_{3}-\mathrm{N}: \mathrm{NO}_{3}-\mathrm{N}$

Table 2. RAINFAll NITROGeN AT SEVERAL SITES IN NORThER NIGERIA, JEN AT SEVERAI SITK
JUNE-SEPTEMBER 1969

$\begin{array}{lcc}\text { Site } & \begin{array}{c}\text { Rainfall } \\ (\mathrm{mm})\end{array} & \begin{array}{c}\text { Mineral-N field addition } \\ \left(\mathrm{kg} / \text { hectare }^{-1}\right)\end{array} \\ \text { Katsina } & 436 \cdot 9 & 2 \cdot 51 \\ \text { Kano } & 322.6 & 2 \cdot 48 \\ \text { Kontagora } & 843.3 & 3.46 \\ \text { Chafe } & 843.3 & 3.48 \\ \text { Minna } & 1,066.8 & 2 \cdot 87 \\ \text { Samaru I } & 873.8 & 2 \cdot 54 \\ \text { Samaru II } & 955.0 & 3.13\end{array}$

* Figures in this column, except those for Samaru II, are based on the volume of water collected, which was subject to evaporation losses from the collecting bottle. Samaru II data are taken from Table 1 and included for
comparison.

The figures of $4.5 \mathrm{~kg} /$ hectare $^{-1}$ per year for mineral nitrogen and of 1.26 for the mean ratio of $\mathrm{NH}_{4}-\mathrm{N}$ to $\mathrm{NO}_{3}-\mathrm{N}$ are of similar magnitude to other reported values ${ }^{4,6}$ for tropical areas where rainfall is comparable. We conclude that the values published earlier were erroneous ${ }^{1}$, and that in the Samaru area rainfall nitrogen makes little contribution either to the current crop requirement or to the build-up of soil nitrogen under local bush fallow noted by E. Jones.

M. J. JoNES

Soil Science Department,

A. R. BRomfteld

Institute for Agricultural Research,

Samaru, Zaria, Nigeria.

Received March 17, 1970.

1 Jones, E., Nature, 188, 432 (1960).

2 Stevenson, C. M., Quart. J. Roy. Met. Soc., 94, 56 (1968).

s Eguer, H., and Eriksson, E., Tellus, \%, 134 (1055).

"Allison, F. E., in Soil Nitrogen (Amer. Soc. Agron., 1965).

s Wetselaar, R., and Hutton, J. T., Austral. J. Agric. Res., 14, 319 (1963).

- Meyer, J., and Pampfer, E., Nature, 184, 717 (1959). 